\title{
Implementation Of Registration Of Transfer Of Rights Reserved Land For Endowments By Permen Atr Bpn No. 2 Of 2017 In Pati Regency
}

\author{
Rubin Pratama ${ }^{1}$ and Akhmad Khisni ${ }^{2}$
}

Abstract. The purpose of this study was to identify and analyze: 1) Implementation of Registration of Transfer of Rights Reserved Land For Endowments By Permen ATR BPN No. 2 Of 2017 in Pati regency. 2) As a result of the Law of Registration of Transfer of Rights Reserved Land For Endowments By Permen ATR BPN No. 2 Of 2017 in Pati regency. 3) Barriers and Solutions in the Process of Registration of Transfer of Rights Reserved Land For Endowments By Permen ATR BPN No. 2 Of 2017 in Pati regency.

The approach method in this research is juridical empirical research that emphasizes the behavior of individuals or communities in connection with the law. The data used are primary and secondary data obtained through interviews and literature, while the method of data analysis was done with descriptive qualitative analilis.

Results of the research results can be concluded: 1) The registration of transfer of property rights to land as endowments by Permen ATR BPN No. 2 of 2017 in Pati regency categorized into two, namely for Waqf land registration activities that have not been certified (customary land) and the endowment of land that has been certified. For land that has not berserifikat documents furnished as the Deed of Pledge Waqf, copy of ID / KK, Ffoto copy of ID card / ID holder, a certificate of history of the land, a statement of physical mastery, the power of attorney request, a copy of property tax, proof of the right base / proof of ownership, a letter of disputes and probate Nadzir. As for the registration of land that has been certified requirements document completeness namely Deed Pledge endowment, land title certificates, copy of ID / KK Applicant, copy of ID / KK owner rights, petition, revelation of the grace period endowments, probate Nadzir, a statement of the land is not dispute, a statement of the land / building physically controlled, and evidence of CNS / PPH. 2) The legal consequences transitional registration of land titles for endowments, namely the status of Waqf land rights be have legal certainty. Waqf land registration set forth in Regulation ATR BPN Number 2 of 2017 concerning Procedures in the Ministry of Waqf Land Registration BPN ATR is a target to hold a legal simplicity. 3) Barriers still the majority community in Pati regency are still reluctant to take care certificate donated land, because of the assumption that the Waqf land certification process requires very expensive, the government's solution is to conduct information dissemination and outreach to the community.

Keywords: Endowments; Land Registry; BPN.

\section{Introduction}

Constitution of the Republic of Indonesia in 1945 laid the foundation, as in Article 33 paragraph (3) that the earth and water and natural resources contained in it are controlled by the state and used for the greatest prosperity of the people. From these basic rules can be seen that the prosperity of society is a major goal in the utilization

\footnotetext{
${ }^{1}$ Student Master of Law, Sultan Agung Islamic University Semarang, DPUTR Staff of Pati regency, email rubin.pratama@gmail.com

${ }^{2}$ Lecturer in Faculty of Law, Sultan Agung Islamic University
} 
of the function of the earth, water and air space and the natural riches contained therein. ${ }^{3}$

The transfer of land property may occur through legal acts transitional land rights. Among other legal acts for the sale and purchase, inheritance, grants, endowments, exchange auctions and so on. The right transition induced removal of the right to possession of one person to another one legal act in the transfer of land property is Waqf. According to ATR BPN Regulation No. 2 In 2017, the Waqf is a legal act Wakif to separate and / or transferring part of their wealth either permanently or for a specified period in accordance with their interests for purposes of worship and / or the general welfare according to sharia. ${ }^{4}$

Endowments based MUI's Fatwa, was handed over the land or other objects used by Muslims without damaging or spend substantially to a person or legal entity that can be utilized for the benefit of Muslims, such as donating land for the construction of mosques, Islamic schools, boarding schools, boarding orphans strays and so on. ${ }^{5}$

The provisions contained meanings of land subject closely related to the worship and other sacred purposes, one of them with endowment ground, in the agrarian law of national attention. By Government Regulation No. 28 of 1997, donations of land property rights is a legal act of a person or legal entity that is separate part of their wealth in the form of lands and institutionalize forever for the sake of worship or other public interests in accordance with the teachings of Islam. ${ }^{6}$

In Article 3 of Regulation ATR BPN No. 2 Of 2017 concerning land endowment Conditions can be:

- Ownership or Land Belongs to Indigenous unregistered.

- Leasehold, Right of Building and Land Use Right in the State.

- Broking / Right of Use on land management rights or rights Reserved.

- Properties on Unit Flats.

- State land. ${ }^{7}$

Endowment soil should be soil or soil-Owned Properties are either entirely or partially free from the burden of bonding, guarantees, encumbrances and disputes, as stipulated in Government Regulation No. 28/1977 Article 4. ${ }^{8}$ According to the Waqf Act No. 41 of 2004 Article 1 (1) states: Waqf is a legal act Wakif to separate and / or transferring part of their wealth either permanently or for a specified period in accordance with their interests for purposes of worship and / or the general welfare according to sharia. ${ }^{9}$

To gain power over land endowment law, it must be made by a deed of endowment pledge by the head of KUA as Waqf Deed Official Pledge. Implementation pledge endowments, as well as the manufacture of the Deed of Pledge Waqf considered valid, if attended and witnessed by at least two witnesses, accompanied by letters of proof of land ownership, certificate of the head of the village, land registration certificate. After the Pledge Deed Endowments are created, conducted registration of donations of land belonging to the Land Office District / City to obtain the certificate. Waqf land titling is

\footnotetext{
3Muhammad Bakri, 2007, Hak Menguasai Tanah Oleh Negara (Paradigma Baru Untuk Reformasi Agraria), Citra Media, Yogyakarta p. 5

${ }^{4}$ Article 1 Regulation ATR BPN No. 2 of 2017 on Procedures for Land Registration in the Ministry of Awqaf ATR BPN

${ }^{5}$ Hamdan Rasyid, 2003, Fiqh Indonesia (Himpunan Fatwa-fatwaaktual), cetakan pertama, Al-Mawardi, Jakarta, p. 294

${ }^{6}$ Adrian Sutedi, 2012, Sertifikat Hak Atas Tanah, Sinar Grafika Jakarta, p.167

${ }^{7}$ Article 3 (1) of the Regulation of the Minister of ATR BPN No. 2 of 2017

${ }^{8}$ Act No. 6 of 1997 on Land Registration Rules Regarding perwakafan Owned Land

${ }^{9}$ Act No. 41 of 2004 article 1 point 1
} 
a national program as the responsibility of government and society. Therefore, to determine the exact amount of donated land in Indonesia, should be held data collection is complete. ${ }^{10}$

Pati Regency is one of the districts that are implementing accelerated certification program Waqf land. At the end of 2018 and then, the Ministry of Religious Affairs (MORA) Pati Regency socialize acceleration Waqf land certification. Socialization activities accelerated certification Nadzir donated land to the associations, organizations and institutions endowments, at the hall of the office MORA Pati regency. Socialization is done in the presence of +100 Nadzir and 20 head of KUA. Socialization of the donated land certification regulation, and cata system certification process until the direction and strategy of certification programs by the National Land Agency (BPN) Pati regency. Waqf land certification refers to the Joint Decree (SKB) The Minister of Religious Affairs and BPN Decree No. 422/2004 on Waqf land certification, and regulation ATR BPN No. 2 in 2017. ${ }^{11}$

Based on this background removed Judicial Review Implementation of Registration of Transfer of Rights Reserved Land For Endowments By Permen ATR BPN No. 2 Of 2017 in Pati Regency ". This study tried to answer the question about the Implementation of the Transitional Registration of Property Rights to Land For Endowments By Permen ATR BPN No. 2 Of 2017 in Pati regency, Effects Registration of Transfer of Rights Reserved Land For Endowments By Permen ATR BPN No. 2 Of 2017 in Pati regency. Obstacles and Solutions in the Process of Registration of Transfer of Rights Reserved Land For Endowments By Permen ATR BPN No. 2 Of 2017 in Pati Regency

\section{Research methods}

The method used in this research is juridical empirical. juridicalempirical ie research that focuses on the behavior of individuals or communities in connection with the law. ${ }^{12}$ Specification of the research is descriptive. Primary data were collected by interview. Type of interview used in this study using a free guided interview, is a combination of free and guided interview. ${ }^{13}$ Secondary data is data obtained from a review of the literature or the review of the literature or library materials related to the problem or research materials that are often referred to legal materials. ${ }^{14}$ Analysis of the data used in this study is a qualitative analysis.

\section{Results and Discussion}

\subsection{Implementation of the Transitional Registration Properties Land For Endowments By Permen ATR BPN No. 2 Of 2017 in Pati Regency}

The registration of land in Pati regency implemented by Act No. 41 of 2004 and its amendments in the Government Regulation No. 25 of 2018, also in the Minister ATR BPN No. 2 of 2017 on Procedures for Land Registration Waqf in the Ministry of Agricultural and Spatial / Land Agency National. As each application for registration of

\footnotetext{
${ }^{10}$ Adrian Sutedi, op.cit, p. 170

11 https://www.patikab.go.id, Accessed February 6, 2019, 22:00 pm

12 Soerjono Soekanto dan Sri Mamadji, 2009, Penelitian Hukum Normatif: Suatu Tinjauan Singkat, Raja Grafindo Persada, Jakarta, p.1

13 Ibid. p. 84

${ }^{14}$ Mukti Fajar dan Yulianto, 2010, Dualisme Penelitian Hukum Normatif dan Empiris, Pustaka Pelajar, Yogyakarta, , p. 156
} 
endowments are divided into two categories, namely land that had not been certified (customary land) and land that has been certified. ${ }^{15}$

For Waqf land registration activities that have not been certified as follows:

- PPAIW on behalf Nadzir come to the District Land Office with the Application for Certification Waqf land in Pati that has been signed and stamped and completing the requisite documents as follows:

- Deed of Pledge Waqf. Deed of pledge Waqf Writer thorough is the Deed KK.11.18.21 / BA.032 / 22/2012. Wakif in this Waqf was Hj. Kunsiati with Nadzir mr. Silaturohim, S.Ag. Endowments object is a piece of wetland parcels 90, area 2,250 $\mathrm{m} 2$ located in the Wegil village, Sukolilo District Pati regency. Benefits endowment was given to Madrasah Yayasan Sunan Prawoto, Wegil Village, Sukolilo District, Pati regency. Pledge endowments made before Head KUA Sukolilo District Mr. Muhammad Shihab who has been appointed as Acting Endowments Pledge Deed. Pledge endowments also witnessed by K. Muhibbin Majid and $\mathrm{H}$. Muayyadu. Pledge endowments held on 30 April 2012. ${ }^{16}$ Pledge Waqf manifested in a Deed of Pledge Endowment and made three (3) copies, the first copy is kept by PPAIW, the second sheet is attached to the letter of the registration application to the District Land Office Pati and the third for the courts that authorize Wagf in this case the court Religion Pati.

- Photocopy of ID / KK

- Photocopy of ID / Identity Own Rights

- Certificate of Land History. Land history certificate must contain clearly switchover history ownership ground. In these endowments are listed under number XIII / 12/2012, explaining that a parcel of land belonging to indigenous recorded in C Village No. 24 Persil 90 broad classes DIII $2250 \mathrm{~m}^{2}$ located in the Wegil village, Sukolilo District, Pati regency.

- Affidavit physical mastery

- The power of attorney request

- Photocopy of property tax

- Evidence pedestal right / proof of ownership

- A letter of dispute

- Probate Nadzir

Probate Nadzir in this Waqf was passed on November 21, the Head of the Religion / Pledge Endowment Deed Official Sukolilo district Pati regency, with the registration number KK.18.21 / BA.03.02 / 75/2009 stating that in the name of the father Silaturrohmi Nadzir, S.Pd been validated as Nadzir on Waqf land located in Sukolilo district. ${ }^{17}$

If the file requested documents are complete, then Nadzir will be given a receipt document containing number registration file and contains the applicant's name, address, type of activity namely land registration was first endowment for the land that has not been certified (indigenous lands) and a list of all documents have been completed. Costs in the land registration application waqf is free. Furthermore, the file will be further examined for purposes of the issuance of the certificate. ${ }^{18}$ Number registration dossier in the application for this endowment is 128574/2018.

- The officer then made Map Locators plot (Validation spatial / check plot). This means that the requested parcels have been mapped in the base map of land

\footnotetext{
${ }^{15}$ Ministry of Religion, 2013, the Waqf Service Standards For Endowments Pledge Deed Official, p. 3

${ }^{16}$ The application for endowments No. 128574/2018 Pati District Land Office

17 Ibid.

${ }^{18}$ Interview with Masriningsih, Officer Counters Pati District Land Office, July 4th, 2019
} 
registration. This mapping is done by the Section Head of Land Infrastructure and Head of Sub. Section Measurement and Basic and Thematic Mapping. ${ }^{19}$

- After the requisite documents are complete, the Land Office will check the soil.

- Furthermore edaphology Committee Chairman Examination Committee convened the land based on the land being applied for.

- After examination of the soil and found no obstacles on the ground then the next stage is a measurement performed by measuring Officer.

- The final stage is the issuance of a certificate by the District Land Office Pati be on behalf Nadzir.

Application for registration of land endowments are derived from indigenous lands and have not been certified in the District Land Office Pati implementation guided by Article 7 of Regulation ATR BPN No. 2 Of 2017, namely:

(1) Land Waqf derived from Indigenous owned land registered as Waqf land on behalf Nadzir.

(2) Application for registration of Waqf on parcels of land referred to in paragraph (1), accompanied by:

(a) Application letter;

(b) Map Parcel / Mail Measure;

(c) Evidence of legal title to land;

(d) AIW or APAIW

(e) Probate Nadzir concerned from the agency that organizes the religious affairs district level;

(f) Affidavit of Nadzir / Wakif or a letter from the Head Village community that the land is not in dispute, cases, seizure and can not be guaranteed

(3) In the case of an application for registration as referred to paragraph (2) have met the requirements in accordance with the provisions of the legislation, the Head of the Land Office issued a decree affirmation as Waqf land on behalf Nadzir. ${ }^{20}$

For Waqf land registration process has been certified there is little difference in the types of documents that must be completed. The author conducted research on the application for registration No. 142628/2019. The registration process is:

- PPAIW on behalf Nadzir come Ke Pati Regency Land Office filed the Application for Certification of Waqf land that has been signed and stamped, by completing the following files:

- Deed of Pledge Endowments; Stages of Creation Deed of Pledge Endowment for land that has not bersertifikan and that has been certified basically similar. In endowments application file number 142628/2019, Wakif is Mr. Imam Sukarno, Nadzir is Mr. Satibi. The object of Waqf is a land settlement, with certificate No. HM. No.01119 / Ps. 61 class D II, spacious $110 \mathrm{~m} 2$. Located in the village of Force Kidul RT. 005/001 Tambakromo District of Pati regency. This land endowment to the mosque. Pledge endowments performed in the presence of the Head of the District KUA Tambakromo Mr. Sukardi who has been appointed as Acting Endowments Pledge Deed. Pledge endowments also witnessed by Bambang Sutedjo and Darmani. Pledge endowments held on May 23, 2018. Pledge Waqf Deed of Pledge contained in the form of Endowment with No. W.02 / 03/17/2018 and made three (3) copies, the first copy is kept by PPAIW, the

\footnotetext{
${ }^{19}$ Interview with Mr. Ananta Setyo Cahyono, S.SIT Staff Pati District Land Office, July 4th, 2019

${ }^{20}$ Article 7 (1) - paragraph (3) of the Regulation of the Minister of ATR BPN No. 2 of 2017 on Procedures of Land Registration in the Ministry of AwqafATR BPN.
} 
second sheet is attached to the letter to the registration application Pati Regency Land office and a third for the courts that the Waqf authorize in this case religious court Pati. ${ }^{21}$

- Certificate of Land Rights; For the status of land is the land of land rights (in this case certified property rights), then the release of new rights can then get a certificate endowments. Endowment because the land will be a waiver by the owner and endowments which He swore an irrevocable, we would advise to any person who will do the Waqf land that has been certified in order to split the land certificate in advance before performing endowments. ${ }^{22}$

- Photocopy of ID / KK Applicant

- Copy of ID / KK Owner Rights

- Application letter

- Endorsement Letter Nadzir

- Affidavit land is not disputed

- Affidavit of land / building physically overpowered

- Evidence of CNS / PPH

- After the requisite documents are complete, the office will conduct research and examination of the ground. For the land certificate has not broken then it will be a waiver and solving the certificate first. In Article 4 of the Regulation of the Minister of ATR BPN No. 2 Of 2017 is described onseparation certificate, namely:23

(1) In the event that such Waqf Land Property Rights referred to in Article 3, paragraph (1) letter a will endowment only a portion of the total area, first performed the measurements for the separation certificate.

(2) Separation of the certificate referred to in paragraph (1) made AIW or APAIW, and became the basis for Waqf Land Certificates issued on behalf of Nadzir.

Separation of certificates was done to facilitate the certification process Waqf land has been certified as well as to minimize the occurrence of land disputes to come.

- After examination of the soil and found no problems last stage is the issuance of a certificate by the District Land Office Pati be on behalf Nadzir. Described in Article 5: In the case of leasehold certificates, Broking and Right of Use on land State referred to in Article 3 (1) b of the license if there is a record to be transferred, to be endowment must obtain prior permission from the authorities. ${ }^{24}$

\subsection{Effects Registration of Transfer of Rights of Ownership on Land for Waqf By Permen ATR BPN No. 2 Of 2017 in Pati regency.}

The land registry positive implications on land law in Indonesia. In the practice of public life, a piece of land that has been endowment as a result will have a special status, namely the isolation of the Waqf land of transactions (sale and purchase, lease, grant, inheritance, guarantees, and other forms of transfer). As a result anyway he seems can be categorized as a rechtpersoon (legal entities), which is a legal person has rights and obligations in the life of the law as a legal subject. Said that because the procedure up to the submission, all activities in the community are activities Waqf property itself whose implementation is represented by Nadzir.

\footnotetext{
${ }^{21}$ The application for endowments No. 142628/2019 Pati District Land Office

${ }^{22}$ Interview with Mr. Suratman, head of Sub. Section registration of land rights Pati District Land Office, dated July 4, 2019

${ }^{23}$ Regulation of the Minister of ATR BPN, op.cit, Article 4 paragraph (1) and (2)

${ }^{24}$ Ibid, Article 5
} 
Land registration is essential as evidence of a strong right over land rights to prove as land owners legally. Property rights, thus each the transfer, abolishment and loading with other rights must be registered. Waqf land registration set forth in Regulation ATR BPN Number 2 Of 2017 concerning Procedures in the Ministry of Waqf Land Registration BPN ATR is a target to hold a legal simplicity. The effort toward legal certainty on the ground stated in the provisions of the Articles regulating the registration of land, in Article $19 \mathrm{BAL}$ mentioned to ensure the Legal Certainty of rights over land, BAL government to provide land registration throughout Indonesia, is Recht Cadastre, means to ensure legal certainty, with the convening of land registration, then the parties concerned can easily be mengetahi the legal status of certain lands faces, location, area and boundaries, who is the owner, and the burdens of what attached above the ground. In general, the legal effect of registration of transfer of property rights to land as endowments are:

- Certain rights to someone; That is, with a transfer of registration of property rights for the endowment, the right person becomes clear.

- Circumvention of a dispute; If a piece of land that is already registered endowment, the unavoidable occurrence of land disputes, such as the withdrawal of the donated land, the denial pledge endowment, widely disputed land and boundaries.

- Establishment of a taxation; By knowing how big a piece of land, then based on it can be determined much tax should be paid.

Registration according to the BAL ditujukkan to rights-holders in this case is Wakif and Nadzir, in order to create legal certainty for themselves, for the registration of any transfer, removal and pembebannya will cause a lot of legal complications if it is not registered, but registration is powerful evidence as required by Article 23 paragraph (1), that the property, and any transition, abolishment, and pembebannya with other rights must be registered according to the provisions referred to daam Article $19 \mathrm{BAL}$, as well as with the right to cultivate (Article $32 \mathrm{BAL}$ ) and building rights (BAL 38), including the terms of administration, as well as any transfer and the elimination of those rights should be registered. ${ }^{25}$

\subsection{Obstacles and Solutions in the Process of Registration of Transfer of Rights Reserved Land For Endowments By Permen ATR BPN No. 2 Of 2017 in Pati regency.}

In the process of registration of transfer of property rights to land as Waqf based ATR BPN Regulation No. 2 Of 2017 in Pati Regency, the authors found no significant barriers. Obstacles encountered their authors are still some people in Pati regency are still reluctant to take care certificate donated land, because of the assumption that the Waqf land certification process requires very expensive. This is experienced by people who have been donating the land, but the status of the land is still customary land (soil C) or no certificate of ownership. As an example the case of land in the village endowment Wegil, sub Sukolilo that occurred in 2012 newly registered in Pati Regency Land Office in 2018. The duration of the registration period is in addition to the assumption about the high cost of certification is also due to the lack of public knowledge about the importance of legalization against status of land rights. ${ }^{26}$

Based on research by the author, in fact Pati Regency Office of Religious Affairs in collaboration with the Land Office and the head of KUA throughout Pati regency

\footnotetext{
25 Adrian Sutedi, 2018, Peralihan Hak Atas Tanah dan Pendaftarannya, Sinar Grafika, Jakarta, p.133

${ }^{26}$ Interview with Mr. Sutadi, head of the District Land Office Pati, July 4th, 2019
} 
already provides a solution by multiplying dissemination to the public that confirms the certification fee donated land $\mathrm{Rp} 0$, - or free. This is in accordance with government regulation No. 13 Of 2010 concerning the type and rate of the non-tax revenue types that apply to the national land agency. Socializing was an important moment, in order to complete the certification acceleration Waqf land that is across the head of KUA throughout Pati regency, which also Deed Official Pledge of Waqf (PPAIW). Later, Pati regency MORA warkah prepare the data and donated land, while the District Land Office starch processing completion certificates. In order to accelerate the certification, currently available PTSL (Systematic Land Registration Complete), which donated land certificate issuance costs financed by the Ministry of ATR / BPN.

\section{Closing}

\subsection{Conclution}

Based on the description in the discussion above, the conclusions in the study:

- Implementation of the Transitional Registration Properties Land For Endowments By Permen ATR BPN No. 2 Of 2017 in Pati regency categorized into two, namely: For Waqf land registration activities that have not been certified as follows:

- PPAIW on behalf Nadzir come to the District Land Office Pati with the Application for Certification of Land Waqf already signed and stamped and completing the requisite documents such as the Deed of Pledge Waqf, copy of ID / KK, Ffoto copy of ID card / ID holder, a certificate history of the land, a statement of physical mastery, the power of attorney request, a copy of the property tax, the right base of evidence / proof of ownership, a letter of disputes and probate Nadzir.

- The officer then made Map Locators plot (Validation spatial / check plot).

- After the requisite documents are complete, the Land Office will check the soil. Soil examination conducted by the Committee edaphology A Team IV in accordance with the object of Waqf land

- Examination Committee Session pleaded soil based on soil.

- Measurement of soil by measuring Officer. officers Measure

- The final stage is the issuance of a certificate by the District Land Office Pati be on behalf Nadzir.

For Waqf land registration process has been certified there is little difference in the types of documents that must be completed. The completeness of the file, among others:

- PPAIW on behalf Nadzir come Into Land Office filed the Application for Certification of Land Waqf already signed and stamped, by completing some papers like deed of pledge endowment, land title certificates, copy of ID / KK Applicant, copy of ID / KK holder, petition, revelation of the grace period endowments, probate Nadzir, land is not disputed affidavit, an affidavit of land / building physically controlled, and evidence of CNS / PPH.

- Land Office will conduct research and examination of the ground. For land certificates have not separated it will be a waiver and separation / splitting certificate in advance.

- After examination of the soil and found no problems last stage is the issuance of a certificate by the District Land Office Pati be on behalf Nadzir.

- Effects Registration of Transfer of Rights Reserved Land For Endowments By Permen ATR BPN No. 2 Of 2017 in Pati regency namely the status of Waqf land 
rights be have legal certainty. Land registration is essential as evidence of a strong right over land rights to prove as land owners legally. Property rights, thus each the transfer, abolishment and loading with other rights must be registered. Waqf land registration set forth in Regulation ATR BPN No. 2 Th. 2017 on Procedures for Land Registration in the Ministry of Awqaf ATR BPN is aiming to hold a legal simplicity.

- Obstacles and Solutions in the Process of Registration of Transfer of Rights Reserved Land For Endowments By Permen ATR BPN No. 2 Of 2017 in Pati Regency obstacles encountered their authors are still some people in Pati regency are still reluctant to take care certificate donated land, because of the assumption that the Waqf land certification process requires very expensive. Pati Regency Office of Religious Affairs in collaboration with the Land Office and the head of KUA throughout Pati regency already provides a solution by multiplying dissemination to the public that confirms the certification fee donated land Rp 0, - or free. This is in accordance with government regulation No. 13 Of 2010 concerning the type and rate of the non-tax revenue types that apply to the national land agency.

\subsection{Suggestion}

Suggestions author in this study are:

- To society should be more open mind / open again to follow or learn socialization itself against persolaan pertaining on the ground, such as the importance of land titling, land registration process connection, as well as the fees charged.

- To Nadzir, should be more thorough and meticulous Nadzir again in endowment, because Nadzir is the party charged with the responsibility, so it should be more critical of the government agencies related to Waqf land registration process.

- To the head of KUA / PPAW should play an active role on his obligation to register land endowments, PPAIW also must mengaadakan extension activities for Nadzir and Wakif about the importance of the legality of an endowment.

- To BPN / Land Office, which is a government agency at the district / city should be able to mobilize the Waqf land registration process. BPN can provide then by accepting all kinds of letters to registered origin Wagf land dispute. In addition BPN should also be more transparent about the process of land registration information.

\section{Bibliography}

[1] Adrian Sutedi, 2012, Sertifikat Hak Atas Tanah, Sinar Grafika, Jakarta

[2] Adrian Sutedi, 2018, Peralihan Hak Atas Tanah dan Pendaftarannya, Sinar Grafika, Jakarta

[3] Amir Syarifuddin, 2012, Ushul Fiqh, Kencana Prenada Media Group, Jakarta

[4] Amiruddin, 2012, Pengantar Metode Penelitian Hukum, Rajagrafindo Persada, Jakarta

[5] Athoillah, 2014, Hukum Wakaf (Hukum Benda Bergerak dan Tidak Bergerak dalam Fikih dan Peraturan Perundang-Undangan di Indonesia), Yrama Widya, Bandung

[6] Berkas permohonan wakaf No. 128574/2018 Kantor Pertanahan Kabupaten Pati

[7] Berkas permohonan wakaf No. 142628/2019 Kantor Pertanahan Kabupaten Pati

[8] Dyara, Radhite Oryza, 2018, Panduan Mengurus Tanah Rumah dan Perizinannya, Legality, Yogyakarta

[9] Effendy Perangin, 2005, Hukum Agraria di Indonesia, Suatu Telaah dari Sudut Pandang Praktisi Hukum, Raja Grafindo Persada, Jakarta 
[10] Gunanegara, 2017, Hukum Pidana Agraria. Logika Hukum Pemberian Hak Atas Tanah dan Ancaman Hukum Pidana, PT. Tatanusa, Jakarta

[11] Hamdan Rasyid, 2003, Fiqh Indonesia (Himpunan Fatwa-fatwaaktual), cetakan pertama, Al-Mawardi, Jakarta

[12] Kementrian Agama, 2013, Standar Pelayanan Wakaf Bagi Pejabat Pembuat Akta Ikrar Wakaf (PPAIW)

[13] Komaruddin dan Yooke Tjumparmah, 2000, Kamus Istilah Karya Tulis IImiah, Bumi Askara, Jakarta

[14] Lutfi Effendi, 2004, Pokok-pokok Hukum Administrasi, Edisi Pertama Cetakan Kedua, Bayumedia Publising, Malang

[15] Muhammad Abid Abdullah, 2004, Hukum Wakaf, terj.Ahrul Sani Faturrahman, IIMAN Press, Jakarta

[16] Muhammad Bakri, 2007, Hak Menguasai Tanah Oleh Negara (Paradigma Baru Untuk Reformasi Agraria), Citra Media, Yogyakarta

[17] Muklishin Muzari, Hukum Perwakafan dan Implikasinya Terhadap Kesejahteraan Maysarakat, Pondok Darussalam, Gontor

[18] Mukti Fajar dan Yulianto, 2010, Dualisme Penelitian Hukum Normatif dan Empiris, Pustaka Pelajar, Yogyakarta

[19] Mustafa Edwin Nasution,2005, Wakaf Tunai ( Inovasi Finansial Islam), cet. 1, Progan Studi Timur Tengah dan Islam UI, Jakarta

[20] Soerjono Soekanto dan Sri Mamadji, 2009, Penelitian Hukum Normatif: Suatu Tinjauan Singkat, RajaGrafindo Persada, Jakarta

[21] Act No. 41 of 2004

[22] Act No. 6 of 1997 on Land Registration Rules Regarding endowment Owned Land

[23] BPN ATR Ministerial Regulation No. 2 Of 2017 on Procedures for Land Registration in the Ministry of Awqaf ATR BPN 